\title{
Complete androgen insensitivity syndrome due to a new frameshift deletion in exon 4 of the androgen receptor gene: functional analysis of the mutant receptor
}

\author{
Jean-Marc Lobaccaro ${ }^{a}$, Serge Lumbroso ${ }^{a}$, Nicolas Poujola, Virginie Georget ${ }^{\mathrm{a}}$, Albert O. Brinkmann ${ }^{\mathrm{b}}$, \\ Georges Malpuech ${ }^{c}$, Charles Sultan ${ }^{\mathrm{a}, \mathrm{d}, *}$ \\ ${ }^{a}$ Centre de Recherches de l'Institut National de la Santé et de la Recherche Médicale. INSERM, and Unité de Biochimie Endocrinienne du \\ Développement et de la Reproduction, Hôpital Lapeyronie, Montpellier Cedex, France \\ ${ }^{\mathrm{b}}$ Department of Endocrinology and Reproduction, Erasmus University, Rotterdam, The Netherlands \\ ${ }^{\mathrm{c}}$ Service de Pédiatrie B, Hôtel-Dieu, Clermont-Ferrand, France

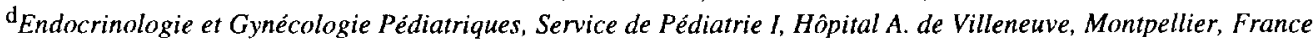

Received 16 January 1995; accepted 13 March 1995

\begin{abstract}
We studied the androgen receptor gene in a large kindred with complete androgen insensitivity syndrome and negative receptorbinding activity. single-strand conformation polymorphism (SSCP) analysis and sequencing identified a 13 base pair deletion within exon 4. This was responsible for a predictive frameshift in the open reading frame and introduction of a premature stop codon at position 783 instead of 919 . The deletion was reproduced in androgen receptor wildtype cDNA and transfected into mammalian cells. Western blot showed a smaller androgen receptor of $94 \mathrm{kDa}$ for the transfected mutated cDNA instead of $110 \mathrm{kDa}$. Androgen-binding assay of the mutated transfected cells assessed the lack of androgen-binding. Gel retardation assay demonstrated the ability of the mutant to bind target DNA; however, the mutant was unable to transactivate a reporter gene. Although the role of the partial deletion in the lack of androgen action was expected, in vitro analyses highlight the role of the abnormal C-terminal portion in the inhibition of the receptor transregulatory activity of the protein causing androgen resistance in this family.
\end{abstract}

Keywords: Androgen receptor; Nuclear receptors; Testicular feminization; Gene deletion; In vitro studies

\section{Introduction}

The syndrome of testicular feminization or complete androgen insensitivity syndrome (CAIS) is an X-linked disorder characterized by a female phenotype along with the failure of Wolffian development in karyotypically $46, X Y$ individuals with intraabdominal or inguinal testes, which are able to normally synthesize androgens (Brown and Migeon, 1987). Individuals with CAIS usually come to medical attention because of inguinal hernia or primary

\footnotetext{
$\sqrt{5}$ Presented in part at the 33rd Annual Meeting of the European Society for Paediatric Endocrinology, Maastricht, June 22-25, 1994 and abstracted in Horm. Res. 41 (1994) 117.

* Corresponding author, Centre de Recherches INSERM, 70 Rue de Navacelles, 34090 Montpellier, France. Tel.: +336733 86 96; Fax: +33 67338327 .
}

amenorrhea at puberty. The phenotype is female with diminished or absent axillary and pubic hair. This disease results from a defective cellular response to androgens due to a non-functional androgen receptor (AR), the mediator of androgen action in cells (Brown and Migeon, 1987). Cloning and sequencing of the AR genc (Chang et al., 1988; Lubahn et al., 1988; Trapman et al., 1988) located on the $\mathrm{X}$ chromosome demonstrated that the AR belongs to a subfamily of steroid hormone receptors within a large superfamily of ligand-responsive DNAbinding transcription factors which share a homology of structure (Evans, 1988). The AR is composed of an amino-terminal domain encoded by the large exon 1, which plays a role in transcriptional activation; a central cysteine-rich DNA-binding domain, composed of two zinc-fingers encoded by exons 2 and 3, respectively; and a carboxy-terminal region, encoded by exons $4-8$, in- 
volved in ligand binding and in the interactions with several heat-shock proteins (HSP) (Evans, 1988). There are few data concerning the secondary and tertiary structures of the $\mathrm{AR}$ or the proteins that interact with it to induce enhancement of androgen-regulated genc transcription. Development of molecular tools to analyze mutant AR genes in CAIS would thus be useful for studying the structure-function relationship of the AR.

Molecular study of patients with CAIS has revealed a large spectrum of point mutations contrasting with a low frequency of gene deletion (McPhaul et al., 1993; Sultan et al., 1993; Patterson et al., 1994; Zhou et al., 1994). Southern blot or enzymatic amplification analyses have shown only eight complete or partial AR gene deletions associated with CAIS (Brown et al., 1988; Ris-Stalpers et al., 1990; Trifiro et al., 1991; Batch et al., 1992; Quigley et al., 1992a,b; MacLean et al., 1993; Beitel et al., 1994). Extensive gene rearrangements thus do not appear to account for a large percentage of patients. Indeed, in a previous work on 40 families, we found no deletions (Lobaccaro et al., 1992; and unpublished data).

In a large kindred with complete androgen insensitivity syndrome, we found a partial deletion in exon 4, encoding part of the carboxy-terminal domain of the AR. To specify the defect of the AR at the molecular level, we analyzed the consequences of the deletion on the protein size and on the AR functional properties, i.e. androgen- and DNA-binding ability along with reporter gene transactivation capacity.

\section{Family and methods}

\subsection{Family}

We studied a French family presenting four cases of CAIS (Fig. 1). Patient III-2 had originally been referred to the Department of Pediatrics of Clermont-Ferrand at 14 years of age, for the presence of an oblong mass in the labia majora. The diagnosis of CAIS was based on the association of primary amenorrhea, absence of pubic and axillary hair, normal breast development in this phenotypical adolescent girl with a $46, \mathrm{XY}$ blood karyotype, and a plasma testosterone concentration of $3.5 \mathrm{nmol} / \mathrm{l}$ (normal value for a Tanner stage III normal boy). The same diagnosis was made for patients III-4, III-6 and III-7, presenting bilateral inguinal hernia, female phenotype and 46, XY karyotype. The right gonad of III-4 had been removed. Pathological examination showed small and regular seminiferous tubes with Sertoli cells and few germinal cells. Interstitial tissue was abundant, hyperplastic and composed of Leydig cells. The four patients had refused the prophylactic removal of their gonads. Fifteen years later, plasma testosterone showed high values of $33.0,16.5,27.0$ and $26.5 \mathrm{nmol} / 1$ (normal range from 12.0 to $24.0 \mathrm{nmol} / 1$ for adult males) for patients III-2 (29 years), III-4 (23 years), III-6 (20 years) and III-7 (18 years) respectively, confirming the presence of functioning testes. We had previously performed an androgenbinding study in the genital skin fibroblasts of patient III4. The number of binding sites and the dissociation constant of the AR were determined from Scatchard analysis using 17-methyl-[ $\left[{ }^{3} \mathrm{H}\right]-\mathrm{R} 1881$ (17 $\beta$-hydroxy-17 $\alpha$-methyl4,9,11-estratrien-3-one, Dupont de Nemours, France) as ligand. AR-binding capacity was undetectable (the normal mean for AR concentrations in genital skin fibroblasts is $650 \pm 200 \mathrm{fmol} / \mathrm{mg}$ DNA).

Moreover, the mother, II-1, had three sisters, II-3, II-4 and II- 6 with primary amenorrhea, absence of pubic and axillary hair, and infertility suggesting the diagnosis of CAIS. They refused to be further examined and were unavailable for any blood karyotyping and/or DNA investigations.

\subsection{Single-strand conformation polymorphism analysis and direct sequencing}

Genomic DNA of patient III-7 was extracted from peripheral blood lymphocytes by phenol-chlorophorm extraction and ethanol precipitation, and the eight exons of the AR gene were amplified by enzymatic amplification (PCR) and analyzed by single-strand conformation polymorphism (SSCP) methods as previously described (Lobaccaro et al., 1993). PCR products of exon 4 were purified after $2 \%$ Nusievc gel clectrophoresis (FMC,

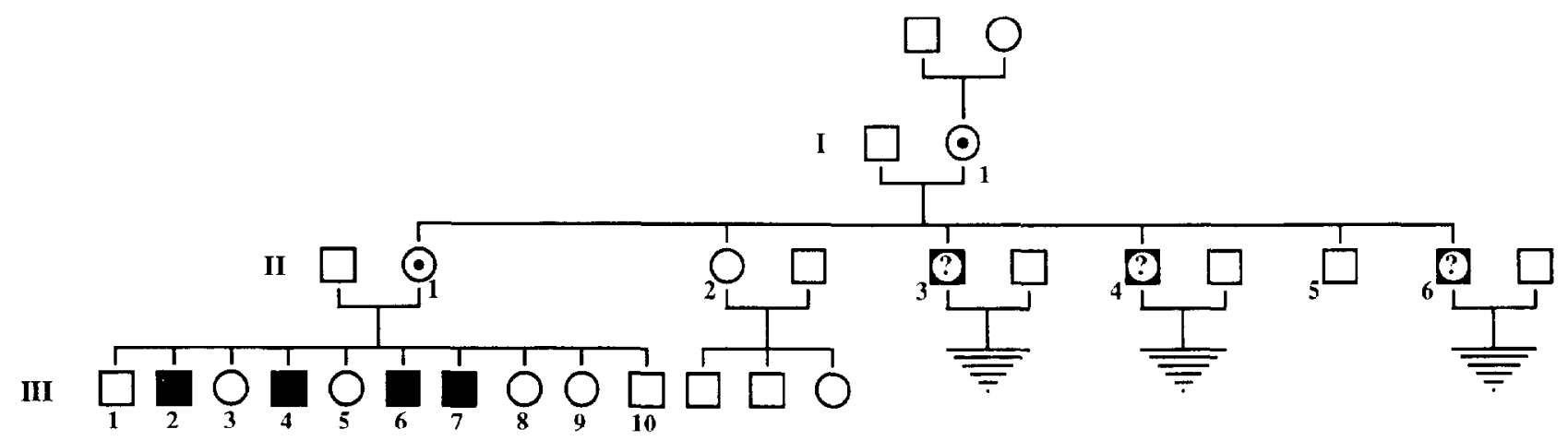

Fig. 1. Pedigree of the family. Black square indicates affected $46, X Y$ patient. Circle with dot indicates obligate heterozygote; Square with question mark indicates potentially affected $46, X Y$ patient. Lined arrow head indicates infertility. 
USA) and phenol-chloroform extraction. Sequencing reactions were repeated twice with two different PCR products with the same primers used for PCR (AR4S, $5^{\prime}$ GCATTGTGTGTTTTTGACCACTG $3^{\prime}$ and AR4A 5' CCCCCTTATCTCATGCTCCC $3^{\prime}$ ) according to Lumbroso et al. (1993).

\subsection{Construction of AR CDNA expression vector with the deleted exon 4}

The wildtype human AR cDNA expression vector was a generous gift from Dr. T.R. Brown (Johns Hopkins University, Baltimore, MD). In this construct (termed pCMV5-hAR), receptor cDNA insert was cloned between the $B g I I I$ and BamHI sites of pCMV5 vector (Brown et al., 1990). To obtain the mutant vector, a KpnI-BamHI fragment (containing both DNA and androgen-binding domain) was cleaved from pCMV5-hAR and subcloned into the corresponding sites of pUC19 (pUC19-hAR). The PCR of the patient's exon 4 was digested by Tth 1111 and StuI. The Tth111-UStuI fragment was purified on Nusieve gel and ligated to pUC19-hAR, whose normal Tth111-I/ StuI fragment had been previously cleaved. Finally, the deleted exon $4 \mathrm{KpnI-BamHI}$ fragment was inserted into the corresponding sites of pCMV5-hAR to yicld pCMV5hAR-del4. All amplifications were performed in DH5 $\alpha$ cells and all steps were verified by sequencing the whole exon 4.

\subsection{Androgen-binding assay}

COS-7 cells were cultured in Dulbecco's minimal essential medium (DMEM Gibco-Brl, France) and 10\% fetal calf serum (FCS), penicillin (100 units/ml), and streptomycin $(100 \mu \mathrm{g} / \mathrm{ml})$. Cells $\left(10^{6}\right)$ were transiently transfected with $20 \mu \mathrm{g}$ of either plasmid construct pCMV5-hAR or pCMV5-hAR-del4 by the calcium phosphate co-precipitation method, cultured for 2 days in $10 \%$ charcoal-steroid depleted FCS and then incubated for $1 \mathrm{~h}$ at $37^{\circ} \mathrm{C}$ with $0.2,0.4,0.67,1.0,1.5$ and $2.5 \mathrm{nM}\left[{ }^{3} \mathrm{H}\right]-$ R1881. The constant of dissociation was determined as previously described (Sultan et al., 1983).

\subsection{Western blot analysis}

Transfected COS-7 cells were lysed in $50 \mu 1$ of $65 \mathrm{mM}$ Tris- $\mathrm{HCl}$ (pH 6.8), $500 \mathrm{mM}$ DTT, SDS $5 \%$, and $5 \mathrm{M}$ urea. After boiling for $10 \mathrm{~min}$ and centrifugation at $13000 \mathrm{rev} . / \mathrm{min}$ for $10 \mathrm{~min}$, one-third of the supernatant was electrophoresed in SDS/PAGE and blotted and immunostained with antibody SpO61 (diluted 1:2000), a polyclonal antibody directed against the $\mathrm{N}$-terminal domain of the human AR, as previously described (van Laar et al., 1989).

\subsection{Gel-retardation assay}

COS-7 $\left(8 \times 10^{5}\right)$ cells transfected with $10 \mu \mathrm{g}$ of plasmid were incubated with $10^{-6} \mathrm{M}$ R 1881 for $24 \mathrm{~h}$, lysed in $60 \mu \mathrm{l}$ of $10 \mathrm{mM}$ Tris- $\mathrm{HCl}(\mathrm{pH} 7.5)$, EDTA
$1 \mathrm{mM}$, DTT I mM, KCl $400 \mathrm{mM}$, glycerol $10 \%(\mathrm{KCl}$ buffer), leupeptine $1.9 \mathrm{mM}$, pepstatine $1.32 \mathrm{mM}$, apoprotein $0.14 \mathrm{mM}$, PMSF $41 \mathrm{mM}$, chymostatine $2 \mathrm{mM}$ and antipaine $2 \mathrm{mM}$ (anti-proteases) by three cycles of freezethawing. Cells were then centrifuged at $4^{\circ} \mathrm{C}$ at $6000 \mathrm{rev} . / \mathrm{min}$ for $1 \mathrm{~min}$ and the supernatant recovered. The interaction of androgen-AR complexes with target DNA was studied by a mobility shift assay using synthetic complementary oligonucleotide probe obtained by annealing the single-strand oligonucleotides 5' GATCTCAGAACACTGTGTTCTGA $3^{\prime}$ and $5^{\prime}$ CTAGTCAGAACACAGTGTTCTGA $3^{\prime}$, containing a glucocorticoid response element (GRE, underlined sequences) derived from the sequence of the GRE previously defined in the mouse mammary tumor virus (Payvar et al., 1983). Two microliters of this cell extract were incubated at $4^{\circ} \mathrm{C}$ in an equal volume of $\mathrm{KCl} 50 \mathrm{mM}, \mathrm{K}_{3} \mathrm{PO}_{4} 20 \mathrm{mM}(\mathrm{pH} \mathrm{7.4)}$, $\mathrm{MgCl}_{2} 1 \mathrm{mM}, \beta$-mercaptoethanol $1 \mathrm{mM}$, glycerol $20 \%$ and $2 \mu \mathrm{g}$ of poly [d(I-C)] to avoid unspecific binding, for $15 \mathrm{~min}$. In certain tubes, SPO61 antibody was added and incubated for $15 \mathrm{~min}$ at $4^{\circ} \mathrm{C}$. Last, $10000 \mathrm{cpm}$ of the probe, labeled with Klenow polymerase and $\left[\alpha^{32} \mathrm{P}\right]-\mathrm{dCTP}$ to a specific activity of at least $10^{7} \mathrm{cpm} / \mu \mathrm{g}$, was added for $15 \mathrm{~min}$. Electrophoresis was performed on $4.5 \%$ acrylamide gel (acrylamide/bisacrylamide, 38:1), TBE $0.25 \times$ (TBE $1 \times: 0.1 \mathrm{M}$ Tris-HCl, pH 8.0, 0.083 M boric acid, $20 \mathrm{mM}$ EDTA) at $20 \mathrm{~mA}$ for $90 \mathrm{~min}$ in a cold room. The gel was then dried and autoradiographed for $24 \mathrm{~h}$ with an intensifying screen.

\subsection{Luciferase activity and $\beta$-galactosidase}

For transcription studies, $2 \times 10^{5} \mathrm{CV}-1$ cells were transfected with $100 \mathrm{ng}$ of either pCMV5-hAR or pCMV5-hAR-del4, $500 \mathrm{ng}$ of pTAT-TK-Luc, a reporter plasmid construct [firefly structural luciferase gene under control of rat tyrosine amino transferase promoter], and $500 \mathrm{ng}$ of pCMV5- $\beta$-galactosidase, an internal control plasmid. Transfected CV-1 cells were cultured for 1 day in $10 \%$ charcoal-steroid depleted FCS, incubated for 1 day with various concentrations of DHT $\left(10^{-9}\right.$ and $10^{-8} \mathrm{M}$ ) or ethanol as control, and then lysed in $300 \mu \mathrm{l}$ of $25 \mathrm{mM}$ Tris-HCl (pH 7.8), 2 mM EDTA, 2 mM DTT, $10 \%$ glycerol and $1 \%$ Triton X-100 final solution. Extract (100 $\mu \mathrm{l})$ was added to $100 \mu \mathrm{l}$ of $270 \mu \mathrm{M}$ coenzyme A (lithium salt), $470 \mu \mathrm{M}$ luciferine, $530 \mu \mathrm{M}$ ATP, $20 \mathrm{mM}$ Tris- $\mathrm{H}_{3} \mathrm{PO}_{4}$ (pH 7.8), $1.05 \mathrm{mM} \mathrm{MgCl}, 2.7 \mathrm{mM} \mathrm{MgSO}$, $0.1 \mathrm{mM}$ EDTA, and $33 \mathrm{mM}$ DTT. Luciferase activity was measured on an LKB luminometer. $\beta$-Galactosidase was assayed on $50 \mu \mathrm{l}$ of cell extract. The standard assay was performed by adding an equal volume of the assay $2 \times$ buffer ( $200 \mathrm{mM}$ sodium phosphate, $\mathrm{pH} 7.3,2 \mathrm{mM} \mathrm{MgCl}_{2}$, $100 \mathrm{mM} \beta$-mercaptoethanol) which contained $1.33 \mathrm{~g} / \mathrm{l}$ of substrate $o$-nitrophenyl- $\beta$-D-galactopyranoside. Samples were incubated for $60 \mathrm{~min}$. Absorbance at $420 \mathrm{~nm}$ was read after addition of $500 \mu \mathrm{l}$ of $\mathrm{Na}_{2} \mathrm{CO}_{3}$ with a spectrophotometer. 


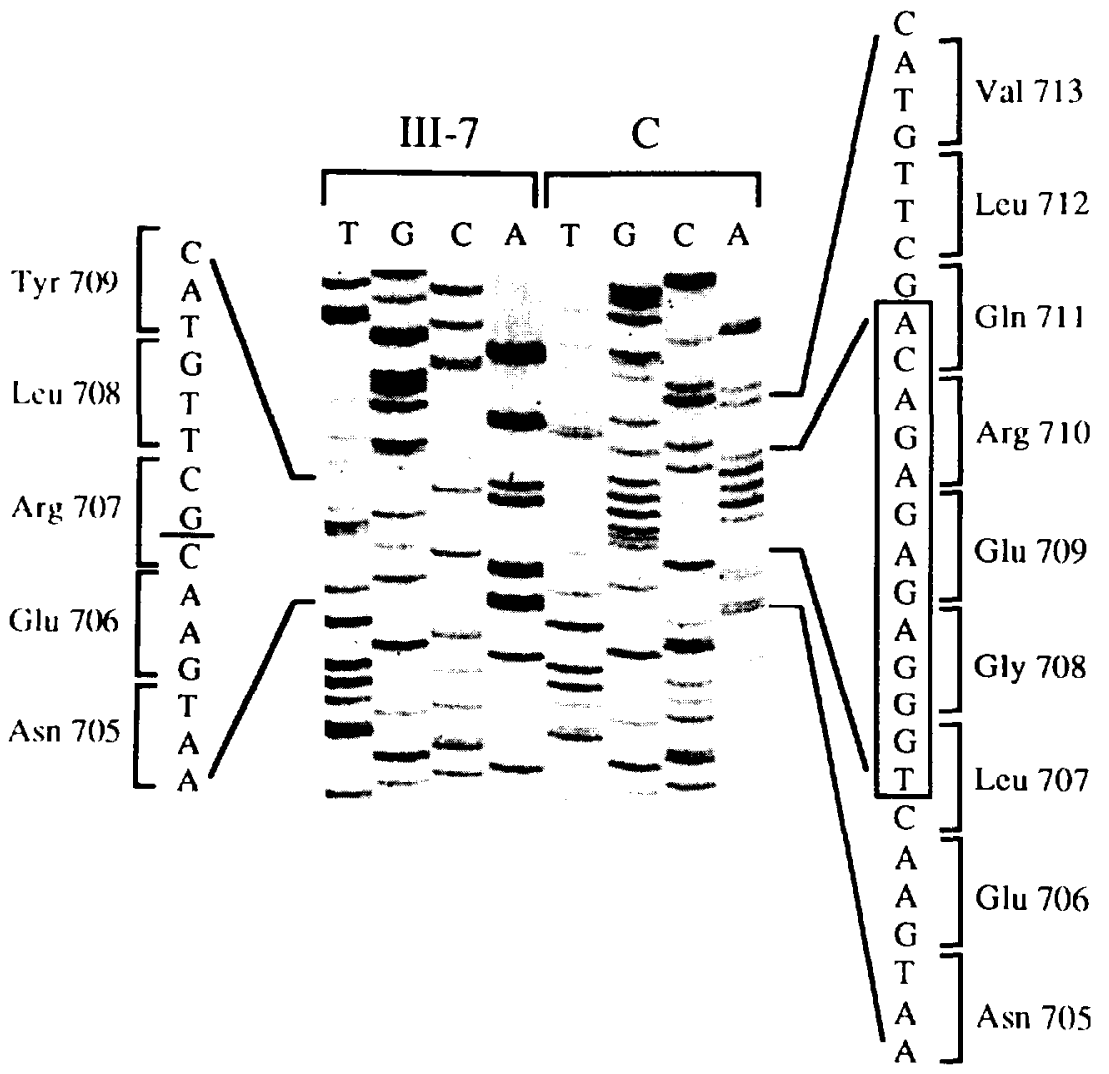

Fig. 2. Partial sequence of androgen receptor exon 4 of patient III-7 compared to C. The deleted 13 base pairs are boxed. Single-letter amino acid code is used and the number of amino acids is indicated in the margins (according to Lubahn et al., 1989).

\section{Results}

\section{I. Identification of the partial AR gene deletion in exon 4}

Evaluation of exons amplified by polymerase chain reaction, using a $1.2 \%$ agarose gel electrophoresis to determine product size, revealed no gross abnormalities in either patient III-7 or a control for exons $1-8$. To screen for minor gene alterations, amplified exuns were further investigated by SSCP analysis. SSCP indicated a mobility shift in cxon 4 (data not shown), suggesting a scquence alteration. As shown in Fig. 2, sequence analysis of exon 4 revealed a 13 base pair deletion from position 2911 to 2923 (between Leu707 and Gln711, sequence numeration according to Lubahn et al. (1989)). This partial deletion created a shift in the open reading frame that interfered with the translation of downstream exons. Moreover, a premature stop codon was introduced at position 783 . Translation of the deleted AR mRNA would thus result in an abnormal and $\mathrm{C}$-terminal truncated protein (782 amino acids versus 919 in the wildtype AR).

\subsection{Western blot of the transfected mutant $A R$}

To investigate whether the deleted gene could be translated and to calculate the size of the AR protein produced, an AR-deleted expression vector was constructed since the original fibroblasts were lost and the family did not consent to another genital skin biopsy. After transient expression in COS-7 cells, SDS-PAGE and western blot, the presence of comparable amounts of the wildtype (110 kDa, calculated molecular mass $99 \mathrm{kDa})$ and mutant ( $94 \mathrm{kDa}$, calculated molecular mass $82 \mathrm{kDa}$ ) proteins was demonstrated (Fig. 3). The discrepancy of approximately $12 \mathrm{kDa}$ between calculated and SDS-PAGE apparent masses was probably due to structural aspects of the Nterminal domain which influences the mobility on SDSPAGE; indecd, dclctions or truncations at the C-terminal part still have this discrepancy of $12 \mathrm{kDa}$.

\subsection{Androgen-binding capacity of the mutant $A R$}

To confirm that the mutant lacked the carboxyterminal function, androgen binding was examined by whole cell binding of $\left[{ }^{3} \mathrm{H}\right] \mathrm{R} 1881$ in COS-7 cells. The dissociation constant $\left(K_{d}\right)$ of the pCMV5-hAR-del4 vector product was undetectable whereas the transfected wildtype showed a $K_{\mathrm{d}}$ of $0.5 \mathrm{nM}(N=0.5 \pm 0.3 \mathrm{nM})$ (data not shown).

\subsection{DNA-binding properties of the mutant $A R$}

In order to study the DNA-binding capacity of the deleted AR, gel shift assays were performed. No differences in the DNA-binding property were found between the 


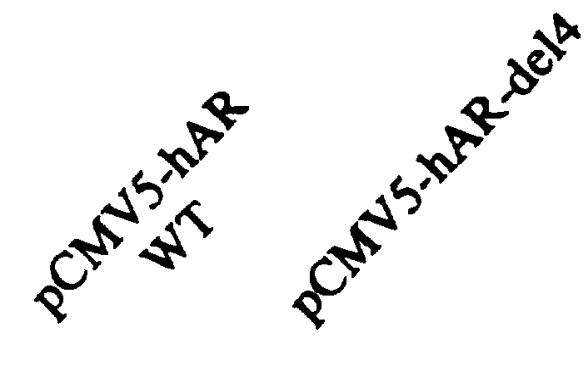

202

133

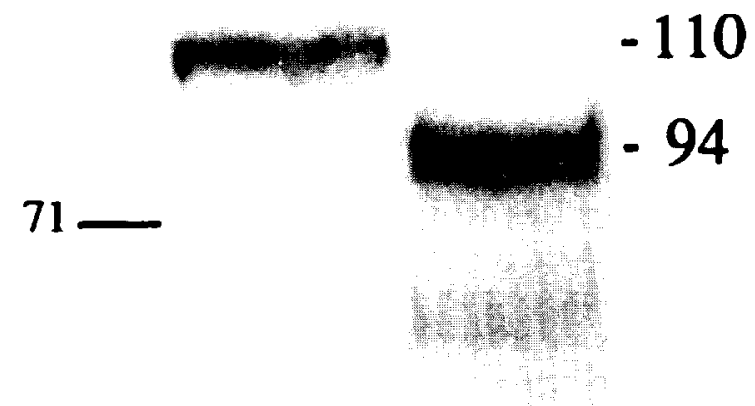

Fig. 3. Immunowestern blot analysis of pCMV5-AR protein, the wildtype AR, and pCMV5-AR-del4, with the deleted AR expressed in COS-7 cells and immunostained with antibody SpO61. The protein band of around $50-60 \mathrm{kDa}$ is probably due to proteolytic breakdown. wildtype and the mutant AR (Fig. 4). Additionally, the gel retardation experiments performed after pre-incubation of the AR with an antibody that recognizes $\mathrm{N}$-terminal sequence (van Laar et al., 1989) showed a supershift of the receptor-DNA complex generated by the wildtype receptor with the GRE. This confirmed that the retardation was not artefactual. This supershift was also observed for the deleted receptor (Fig. 4) and, as already observed by other groups (De Vos et al., 1994), the addition of the antibody enhanced the interaction of AR with target DNA. It was hypothesized that the antibody stabilizes either dimerization of the AR or a conformation conducive to DNA binding.

\subsection{Capacity of the deleted receptor to stimulate the rat tyrosine amino transferase promoter}

To highlight the capacity of the mutant AR to stimulate androgen-responsive genes, transcriptional activity was determined in the co-transfection assay in CV-1 cells by enhancement of luciferase activity with various concentrations of androgen. Data are expressed as arbitrary units, corrected by the level of $\beta$-galactosidase activity. In the presence of androgens, CV-1 cells transfected with pCMV5 hAR demonstrated the presence of a hormoneinduced luciferase activity. However, CV-1 cells transfected with pCMV5-hAR-del4 did not show any luciferase activity in the presence of various concentrations of DHT compared to cells incubated with ethanol or non-

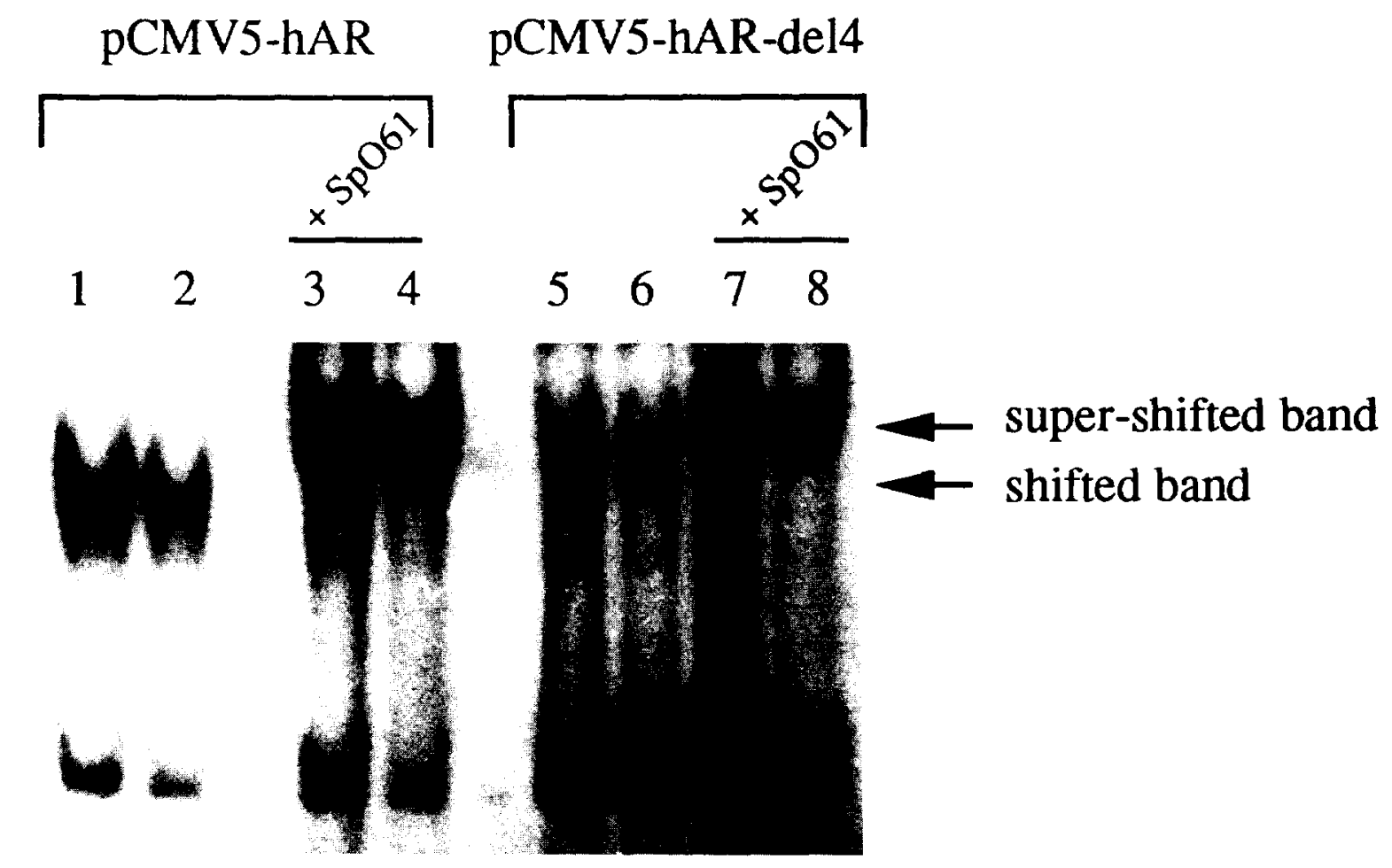

Fig. 4. Mobility shift assay. Shift bands corresponding to the wildtype pCMV5-AR are visible in lanes $1-4$. Shift bands corresponding to pCMV5-ARdel4 are visible in lanes 5-8. Bands in lanes 3,4 and 7,8 are supershifted by the anti-AR SpO61 (diluted 1:2000) (van Laar et al., 1989). 


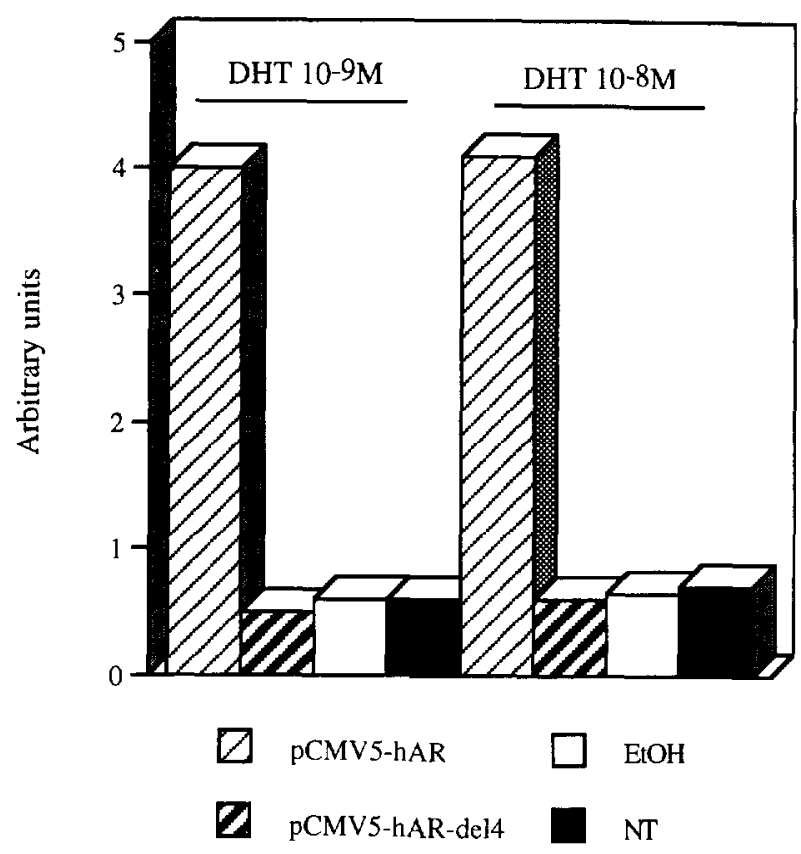

Fig. 5. Enhancement of PTAT-TK-Luc transcription CV-1 cells cotransfected with pCMV5-hAR or pCMV5-hAR-del4. Cells were incubated with DHT at $10^{-8}, 10^{-9} \mathrm{M}$, or ethanol (EtOH); NT, nontransfected cells. The luciferase activity, mean of two values, is indicated in arbitrary units, corrected by $\beta$-galactosidase activity.

transfected cells (Fig. 5). These data indicate that the mutant receptor is not constitutively active.

\section{Discussion}

The action of androgens on target cells occurs via the classical and complex steroid receptor pathway. Any gene alterations of the AR that impair androgen action are thus responsible for androgen insensitivity syndrome. As far as we know, few AR gene rearrangements, such as deletions, have been described in CAIS, whereas nearly $100 \mathrm{AR}$ gene point mutations have been reported (for review see McPhaul et al., 1993; Sultan et al., 1993; Patterson et al., 1994; Zhou et al., 1994). The AR gene rearrangement we describe is the first partial exon 4 deletion which causes a frameshift in the open reading frame and, is associated with CAIS. Exon 4 is rarely affected by gene rearrangements: indeed, to date, only four amino acid missense mutations and one trinucleotide deletion without frameshift have been reported in patients with CAIS. Conversely, a surprising deletion of the entire exon 4 has been described by Akin et al. (1991) using PCR in a man with an isolated azoospermia. How a complete exon deletion causes such a minor form of AIS while point mutations of the same exon cause the complete form has not been elucidated.

The deletion we describe here introduces a premature stop codon after a frameshift (Fig. 6). Two other frameshifts have been described in patients with CAIS by Batch et al. ( 1992) in the large exon 1. The authors reported a single deletion mutant at position 127 and a four nucleotide insertion at position 202. It is interesting to note that
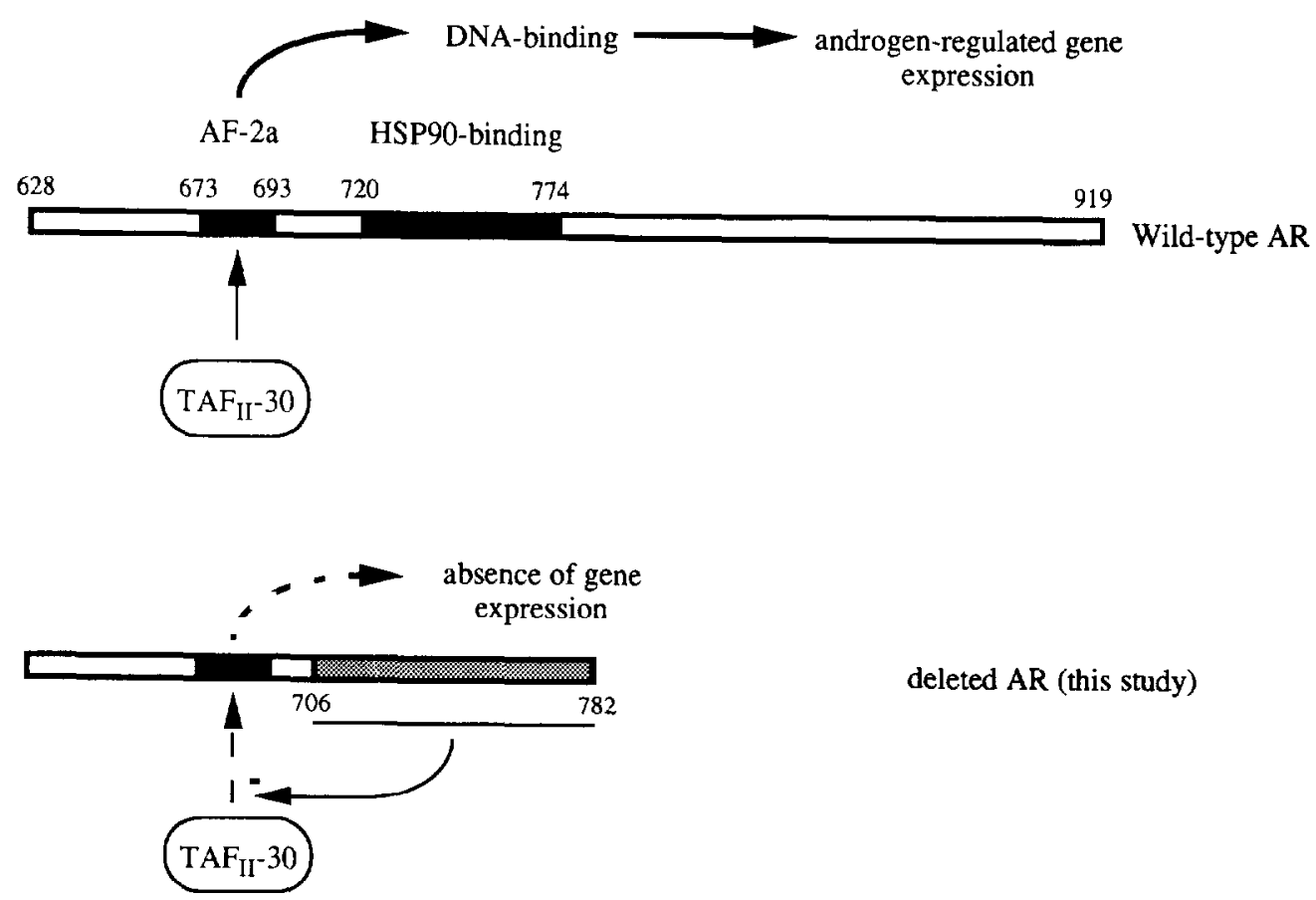

deleted AR (this study)

Fig. 6. Hypothetical consequences of the frameshift on the transcriptional capacity of the deleted AR. Schematic representation of the androgenbinding domain of both wildtype and deleted AR. AF-2a (Pierrat et al., 1994) and HSP-binding site (Marivoet et al., 1992) are indicated. The numbering is according to Lubahn et al. (1989). Dotted area indicates abnormal amino acid sequence. The foreign C-terminal amino acids would inhibit the $\mathrm{TAF}_{\Pi \mathrm{I}}-30$ binding to AF-2a and causes the inactivity of the truncated AR in the absence of hormone. 
a reinitiation of translation at methionine residue sites downstream of a frameshift mutation has been described in Tfm mice (Young et al., 1989; Charest et al., 1991; Gaspar et al., 1991) and in a patient with CAIS (Zoppi et al., 1992). Even though reinitiation is inefficient, it leads to the synthesis of low levels of a receptor comprising the DNA- and androgen-binding domains. Reinitiation thus leads to the production of low levels of N-terminal truncated AR with androgen-binding activity. In the mutant we describe, reinitiation of translation could theoretically occur at several ATG triplets, independently of the open reading frame (at position $734,742,745,749$, etc. of the wildtype AR) and, to test this hypothesis, the use of antibody against the end of the C-terminal domain would be useful.

In vitro analyses have shown that the deleted $A R$ does not bind androgens and that it is incapable of inducing transactivation of androgen-regulated genes. These results indicate that this gene alteration caused androgen resistance in this family. Ris-Stalpers et al. (1990) reported a mutant AR presenting an aberrant splicing site, introducing a $123 \mathrm{bp}$ deletion in the mRNA responsible for the presence of the portion from amino acid 683 to 723 (numbering according to Lubahn et al., 1989) and that it is unable to transactivate androgen-regulated genes. Interestingly, Simental et al. (1991) demonstrated that AR lacking the end portion of the androgen-binding domain from amino acid 660 may show constitutive transcriptional activity of $13 \%$, as described for androgen (Jenster et al., 1991) or other steroid receptors (Evans, 1988). Analysis of discrepancies in constitutive transcriptional activity among mutant ARs described by Ris-Stalpers et al. and by ourselves, and the one studied by Simental et al. raised several questions in terms of AR structurefunction relationship. Firstly, a low expression of mutant $A R$ in our experiments can be ruled out since comparable amounts of the wildtype and mutant proteins has been shown by western blot (Fig. 2). Secondly, involvement of modification of HSP90 binding can be questioned. Indeed, the binding of HSP to AR is supposed to play a role in the inhibition of transcription capacity in the absence of ligand (Veldscholte et al., 1992). The common part found in the mutants described by Ris-Stalpers et al. and our group, which was not found in the AR constructed by Simental et al., is the portion from amino acid 660 to 683 . One could speculate on the importance of this portion for the non-activation of the AR in the absence of androgen, and for the HSP90 binding. However, Marivoet et al. (1992), using HSP90 antibodies, directly indicated that a specific sub-region of the carboxy-terminal half of the rat AR (from residues 720 to 774 in the human AR) was required for the interaction with HSP90. Thirdly, the difference in constitutive transcriptional activity may be related to a change in the interaction of the deleted AR with transcription factors because of the 76 foreign C-terminal amino acids resulting from the frameshift. Pierrat et al.
(1994) described a region of the human estrogen receptor, AF-2a, that contains an autonomous activation, which is highly conserved in the steroid receptor and located within positions 673-693 in the human AR, a region present in our mutant. This domain interacts with $\mathrm{hTAF}_{\Pi^{-}} 30$, a human TATA-binding protein-associated factor (Jacq et al., 1994). It has been suggested by the authors that the activating domain constituted by the AF- 2 a region of steroid receptors interacts with both basal transcription factors and $\mathrm{hTAF}_{\mathrm{I}} 30$ for the transcriptional activation. The deleted AR would thus be transcriptionally active. The abnormal C-terminal domain would be able to cover the AF-2a region and inhibit the binding of $\mathrm{hTAF}_{\mathrm{II}^{-}} 30$ to this region, leading to an inactive AR (Fig. 6). To confirm this hypothesis, which may highlight the receptor defect at the molecular level, the use of antibodies against $\mathrm{hTAF}_{\mathrm{II}}-30$ would be useful for studying the abnormal interaction between the deleted $A R$ and this transcription factor.

In conclusion, as previously claimed by several investigators, androgen resistance could serve as a privileged model for analyzing the molecular action of androgens within target cells. This new deletion in the androgenbinding domain, even though it introduces a frameshift, provides more insight into the mechanisms leading to androgen-regulated gene transactivation. Our data highlight the complexity of the genetic mechanisms leading to androgen insensitivity.

\section{References}

Akin, J.W., Behzadian, A., Tho, S.P.T. and McDonough, P.G. (1991) Am. J. Obstet. Gynecol. 165, 1891-1894.

Batch, J.A., Williams, D.M., Davies, H.R., Brown, B.D., Evans, B.A.J., Hughes, I.A. and Patterson, M.N. (1992) Hum. Mol. Genet. 1, 497503.

Beitel, L.K., Prior, L,, Vasiliou, D.M., Gottlieb, B., Kaufman, M., Lumbroso, R., Alvarado, C., McGillivray, B., Trifiro, M. and Pinsky, L. (1994) Nature Genet. 3, 21-27.

Brown, T.R., Lubahn, D.B., Wilson, E.M., French, F.S., Migeon, C.J. and Corden, J.L. (1990) Mol. Endocrinol. 4, 1759-1772.

Brown, T.R., Lubahn, D.B., Wilson, E.M., Joseph, D.R., French, F.S. and Migeon, C.J. (1988) Proc. Natl. Acad. Sci. USA 85, 81518155.

Brown, T.R. and Migeon, C.J. (1987) in Hormone Resistance and Other Endrocrine Paradoxes (Cohen, M.P. and Foa, P.P. eds.), pp. 157203, Springer Verlag, New York.

Chang, C., Kokontis, J. and Liao, S. (1988) Science 240, 324-326.

Charest, N.J., Zhou, Z., Lubahn, D.B., Olsen, K.L., Wilson, E.M. and French, F.S. (1991) Mol. Endocrinol. 5, 573-581.

De Vos, P., Schmitt, J., Verhoeven, G. and Stunnenberg, H.G. (1994) Nucleic Acids Res. 22, 1161-1166.

Evans, R.M. (1988) Science 240, 889-895

Gaspar, M.L., Meo, T., Bourgarel, P., Guenet, J.L. and Tosi, M. (1991) Proc. Natl. Acad. Sci. USA 88, 8606-8610.

Jacq, X., Brou, C., Lutz, Y., Davidson, I., Chambon, P. and Tora, L. (1994) Cell 79, 107-117.

Jenster, G., van der Korput, H.A.G.M., van Vroonhoven, C., van der Kwast, T.H. and Brinkmann, A.O. (1991) Mol. Endocrinol. 5, 1396-1404.

Lobaccaro, J.M., Belon, C., Chaussain, J.L., Job, J.C., Toublanc, J.E., 
Battin, J., Rochiccioli, P., Bernasconi, S., Bost, M., Bozzola, M., Bouccekine, N., Burési, C., Chaabouni, H., Hachicha, M., LargetPiet, L., Leconte, P., Limal, J.M., Magnin, G., Malpuech, G., Moraine, C., Nivelon, J.L., Ranke, M., Schonberg, D., VanderSchueren, M., Moustarih, R., Terraza, A. and Sultan, C. (1992) Horm. Res. 37, 54-59.

Lobaccaro, J.M., Lumbroso, S., Belon, C., Galtier-Dereure, F., Bringer, J., Lesimple, T., Namer, M., Cutuli, B.F., Pujol, H. and Sultan, C. (1993) Hum. Mol. Genet. 2, 1799-1802.

Lubahn, D.B., Brown, T.R., Simental, J.A., Higgs, H.N., Migeon, C.J., Wilson, E.M. and French, F.S. (1989) Proc. Natl. Acad. Sci. USA 86, 9534-9538.

Lubahn, D.B., Joseph, D.R., Sullivan, P.M., Willard, H.F., French, F.S. and Wilson, E.M. (1988) Science 240, 327-330.

Lumbroso, S., Lobaccaro, J.-M., Belon, C., Martin-Coignard, D., Chaussain, J.-L. and Sultan, C. (1993) Fertil. Steril, 60, 814-819.

MacLean, H.E., Chu, S.C., Warne, G.L. and Zajac, J.D. (1993) J. Clin. Invest. 91, 1123-1128.

Marivoet, S., Vandijck, P., Verhoeven, G. and Heyns, W. (1992) Mol. Endocrinol. 88, 165-174.

McPhaul, M.J., Marcelli, M., Zoppi, S., Griffin, J.E. and Wilson, J.D. (1993) J. Clin. Endocrinol. Metab. 76, 17-23.

Patterson, M.N., Hughes, I.A., Gottlieb, B. and Pinsky, L. (1994) Nucleic Acids Res. 22, 3560-3562.

Payvar, F., Defranco, D., Firestone, G.L., Edgar, B., Wrange, O., Okret, S., Gustaffson, J.A. and Yamamoto, K.R. (1983) Cell 35, 381-392.

Pierrat, B., Heery, D.M., Chambon, P. and Losson, R. (1994) Gene 143, 193-200.

Quigley, C.A., Evans, B.A.J., Simental, J.A., Marschke, K.B., Sar, M., Lubahn, D.B., Davies, P., Hughes, I.A., Wilson, E.M. and French, F.S. (1992a) Mol. Endocrinol. 6, 1103-1112.
Quigley, C.A., Friedman, K.J., Johnson, A., Lafreniere, R.G., Silverman, L.M., Lubahn, D.B., Brown, T.R., Wilson, E.M., Willard, H.F. and French, F.S. (1992b) J. Clin. Endocrinol. Metab. 74, 927-933.

Ris-Stalpers, C., Kuiper, G.G.J.M., Faber, P.W., Schweikert, H.U., van Rooij, H.C.J., Zegers, N.D., Hodgins, M.B., Degenhart, H.J., Trapman, J. and Brinkmann, A.O. (1990) Proc. Natl. Acad. Sci. USA 87, 7866-7870.

Simental, J.A., Sar, M., Lane, M.V., French, F.S. and Wilson, E.M. (1991) J. Biol. Chem. 266, 510-518.

Sultan, C., Lumbroso, S., Poujol, N., Belon, C., Boudon, C. and Lobaccaro, J.M. (1993) J. Steroid Biochem. Mol. Biol. 16, 519-530.

Sultan, C., Picard, J.-Y., Josso, N. and Migeon, C.J. (1983) Clin. Endocrinol. 28, 565-568.

Trapman, J., Klaassen, P. and Kuiper, G.J. (1988) Biochem. Biophys. Res. Commun. 153, 241-248.

Trifiro, M., Gottlieb, B. and Pinsky, L. (1991) Mol. Cell. Endocrinol. $75,37-47$.

van Laar, J.H., Voorhost-Ogink, M.M., Zegers, N.D., Boersma, W.J.A., Claassen, E., van der Korput, J.A.G.M., Kuizeveld de Winter, J.A., Van der Kwast, T.H., Mulder, E., Trapman, J. and Brinkmann, A.O. (1989) Mol. Cell. Endocrinol. 67. 29-38.

Veldscholte, J., Berrevoets, C.A., Zegers, N.D., Vanderkwast, T.H., Grootegoed, J.A. and Mulder, E. (1992) Biochemistry 31, 7427430.

Young, C.Y.F., Johnson, M.P., Prescott, J.L. and Tindall, D.J. (1989) Endocrinology. 124, 771-775.

Zhou, Z.X., Wong, C., Sar, M. and Wilson, E.M. (1994) Recent Prog. Horm. Res. 49, 249-274.

Zoppi, S., Marcelli, M., Deslypere, J.-P., Griffin, J.E., Wilson, J.D. and McPhaul, M.J. (1992) Mol. Endocrinol. 6, 409-415. 